\section{MENDETEKSI KECURANGAN LAPORAN KEUANGAN MENGGUNAKAN BENEISH RATIO INDEX PADA PABRIK CAMBRIC YOGYAKARTA}

\author{
Chaidir Iswanaji \\ Universitas Tidar \\ J I. Kapten Suparman No.39, Potrobangsan, Magelang Utara, Magelang, Indonesia \\ chaidiriswanaji@gmail.com
}

diterima 17 Februari 2018, direview 18 Februari 2018 direvisi 23 Februari 2018, diterima 05 Maret 2018.

Artikel ini tersedia di website: http://ejournal.umm.ac.id/index.php/jrak Doi: $10.22219 /$ jrak.v8i1.24

\title{
ABSTRACT
}

This study assesses the possibility of financial statements in textile companies in Yogyakarta using three models namely Beneish model, Altman Z-Score and Financial Ratio. The results of this study indicate the presence of risk zones that need to be investigated further by the management. It is recommended that companies create internal audits to provide assurance of the company's operations, the accuracy of financial reporting and regulatory compliance.

Keywords: Detecting Cheating, Beneish Ratio Index, altman Z-Score, Financial Ratio

\section{PENDAHULUAN}

Kecurangan dari perspektif akuntansi dianggap sebagai tindakan yang disengaja yang mengakibatkan adanya suatu kesalahan dalam suatu laporan keuangan yang menjadi fokus audit. Laporan Nations on Occupational Fraud and Abuse oleh ACFE (2014) menyoroti bahwa kasus laporan keuangan palsu mencatat rata-rata kerugian mencapai \$1 juta. Kecurangan keuangan yang biasa dilakukan meliputi kecurangan rincian keuangan atau non-keuangan untuk menyesatkan individu yang bergantung pada pernyataan dalam membuat keputusan ekonomi (I sa, 2011). U mumnya, kecurangan laporan keuangan dilakukan ol eh manajemen atau dengan sepengetahuan mereka dan karena itu umumnya dikenal sebagai penipuan manajemen. Kecurangan laporan keuangan lebih mendapat pengawasan publik menyusul peningkatan jumlah per usahaan yang kolaps akibat kecurangan manajemen. Diperkirakan bahwa sebuah bisnis akan kehilangan pendapatan ratarata $5 \%$. Hal ini tentu berkontribusi terhadap potensi kerugian peni puan tahunan yang diproyeksikan lebih dari \$3,7 triliun dengan menggunakan Produk Domestik Bruto 2013 (ACFE, 2014).

Kecenderungan perilaku berbuat curang bergantung pada tiga unsur, yaitu dirasakannya kebutuhan finansial, peluang dan rasionalisasi. Selain tiga unsur tersebut, tekanan yang dirasakan ol eh pemilik usaha kecil dan karyawan seringkali merupakan motivasi yang cukup bagi banyak individu untuk melakukan tindakan tidak etis tersebut (J ackson, et.al, 2010).

Dalam usaha mengurangi biaya yang terlalu besar, perusahaan tekstil kecil menengah memfokuskan untuk menghasilkan produk yang paling dicari atau diminati kosumen saja (UNDP, 2006). Adapun perkembagan industri tekstil di Yogyakarta sampai saat ini tergolong semakin membaik.

Pertumbuhan produksi Industri Manufaktur Besar dan Sedang (IBS) Triwulanan (q-to-q) triwulan IV tahun 2015 terhadap triwulan III tahun 2015 mengalami pertumbuhan positif sebesar 1,17 persen. Sedangkan laju pertumbuhan produksi IBS triwulan IV tahun 2015 dibandingkan triwulan IV tahun 2014 (yon-y) juga tumbuh positif sebesar 3,71 persen. J ika dibandingkan dengan pertumbuhan produksi industri besar dan sedang I ndonesia, kinerja produksi I ndustri

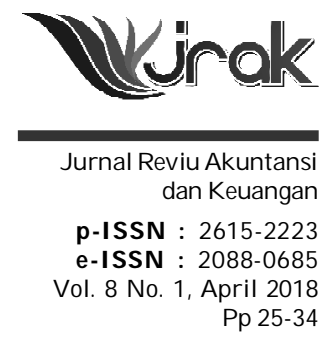


Mendeteksi

Kecurangan

Laporan

Keuangan...
Besar Sedang Provinsi D.I . Yogyakarta (y-on-y) lebih rendah, di mana pertumbuhan industri besar sedang I ndonesia pada triwulan IV tahun 2015 hanya mampu tumbuh sebesar 4,02 persen. (Berita Resmi Statistik D.I . Yogyakarta, 2016).

\section{KAJ IAN PUSTAKA}

\section{Kecurangan}

Kecurangan (fraud) dalam lingkungan bisnis oleh Albrecht dan Albrecht (2002) diklasifikasikan menjadi 5 jenis yaitu:

a. Employee embezzlement atau occupational fraud

Merupakan jenis kecurangan yang dilakukan oleh bawahan kepada atasan. J enis kecurangan ini dilakukan bawahan dengan melakukan kecurangan pada atasannya secara langsung maupun tidak langsung.

b. Management fraud

Merupakan jenis kecurangan yang dilakukan ol eh manajemen kepada pemegang saham, kreditor dan pihak lain yang mengandalkan laporan keuangan. J enis kecurangan ini dilakukan dengan cara menyajikan Iaporan keuangan secara tidak rel evan dan menyesatkan pengguna laporan keuangan.

c. Investment scams

Merupakan jenis kecurangan yang dilakukan oleh individu/ perorangan kepada investor. J enis kecurangan ini dilakukan individu dengan mengelabui atau menipu investor dengan cara menanamkan uangnya dalam investasi yang salah.

d. Vendor fraud

Merupakan jenis kecurangan yang dilakukan oleh organisasi atau perorangan yang menjual barang dan jasa kepada organisasi atau perusahaan yang menjual barang dan jasa. J enis kecurangan ini dilakukan dengan memasang harga terlalu tinggi untuk barang dan jasa atau tidak adanya pengiriman barang meskipun pembayaran telah dilakukan.

\section{e. Customer fraud}

Merupakan jenis kecurangan yang dilakukan oleh pelanggan kepada organisasi atau perusahaan penjual barang dan jasa. J enis kecurangan ini dilakukan pelanggan dengan cara membohongi penjual dengan memberikan kepada pelanggan yang tidak seharusnya atau menuduh penjual memberikan sedikit dari yang seharusnya.

Berdasarkan pengertian di atas dapat disimpulkan bahwa kecurangan merupakan tindakan yang disengaja untuk berbuat kecurangan atau penipuan yang dapat merugikan orang lain.

Salah satu tindakan kecurangan yaitu management fraud. Kecurangan manajemen adalah kecurangan dalam pembuatan laporan keuangan pada sebuah perusahaan. Laporan keuangan merupakan alat yang digunakan untuk melihat kondisi suatu perusahaan. Dalam hal ini manajemen menginginkan agar para pemegang saham dan pengguna laporan keuangan lain mengetahui bahwa kinerja perusahaan terlihat baik. Bagi perusahaan dengan kinerja buruk namun ingin terlihat baik dihadapan para pemegang saham memilih untuk melakukan fraud atau kecurangan dalam pelaporan keuangan.

\section{Laporan Keuangan}

Menurut Fahmi (2012), "Laporan keuangan adalah suatu informasi yang menggambarkan kondisi suatu perusahaan, di mana selanjutnya itu akan menjadi suatu informasi yang menggambarkan tentang kinerja suatu perusahaan". 
Menurut I katan Akuntan Indonesia (2012) Iaporan keuangan merupakan struktur yang menyajikan posisi keuangan dan kinerja keuangan dalam sebuah entitas. Tujuan umum dari laporan keuangan adalah untuk kepentingan umum sebagai penyajian informasi mengenai posisi keuangan, kinerja keuangan dan arus kas dari entitas yang sangat berguna untuk pembuatan keputusan ekonomis bagi para penggunanya. Untuk mencapai tujuan ini laporan keuangan menyediakan informasi mengenai elemen dari entitas yang terdiri dari aset, kewajiban, networth, beban dan pendapatan (termasuk gain dan loss), perubahan ekuitas dan arus kas. Informasi tersebut diikuti dengan catatan yang akan membantu pengguna dalam memprediksi arus kas masa depan.

Laporan keuangan adalah bagian dari proses pelaporan keuangan. Laporan keuangan yang lengkap terdiri dari: neraca, laporan laba rugi, laporan perubahan modal, catatan dan laporan lain serta materi penjelasan yang merupakan bagian integral dari laporan keuangan. Laporan keuangan dikeluarkan sekurang-kurangnya setahun sekali. Banyak pengguna sangat bergantung pada laporan keuangan sebagai sumber utama informasi keuangan atas sebuah perusahaan. Oleh karena itu laporan keuangan seharusnya dikeluarkan dengan mempertimbangkan kebutuhan pengguna.

Menurut Ikatan Akuntan Indonesia (2009) Iaporan keuangan bertujuan untuk:

a. Menyediakan informasi yang menyangkut posisi keuangan, kinerja, serta perubahan posisi keuangan suatu perusahaan yang bermanfaat bagi sejumlah besar pemakai dalam pengambilan keputusan.

b. Laporan keuangan tidak menyediakan semua informasi yang mungkin dibutuhkan pemakai dalam pengambilan keputusan ekonomo karena secara umum menggambarkan pengaruh keuangan dan kejadian masa lalu, dan tidak diwajibkan untuk menyediakan informasi non-keuangan.

c. Laporan keuangan juga menunjukkan apa yang telah dilakukan manajemen atau pertanggungjawaban manajemen atas sumber daya yang dipercayakan kepadanya.

Kecurangan laporan keuangan dapat berkaitan dengan beberapa skema seperti: (1) klasifikasi, pengubahan, atau manipulasi dari catatan keuangan, dokumen pendukung atau transaksi bisnis; (2) kesalahan pencatatan material yang disengaja (material intentional misstatement), penghapusan, atau kesalahan presentasi dari kejadian, transaksi, akun atau informasi signifikan lainnya yang merupakan sumber informasi pembuatan laporan keuangan; (3) kesal ahan aplikasi dan kesalahan interpretasi yang disengaja dan eksekusi standar akuntansi yang sal ah dal am hal penerapan prinsip, kebijakan, dan metode yang digunakan untuk mengukur, mengakui, dan melaporkan kejadian ekonomis dan transaksi bisnis; (4) penghilangan secara sengaja dari pengungkapan atau penyajian pengungkapan yangtidak memadai berkaitan dengan standar, prinsip, praktik akuntansi yang didasarkan pada standar akuntansi yang tersedia yang memiliki kelemahan atau celah yang dapat digunakan perusahaan untuk menutupi substansi ekonomi dari kinerjanya (Rezaee dan Riley, 2005).

\section{Beneish Ratio Index}

Messod D. Beneish mengemukakan teori dalam artikelnya "The Detection of Earnings Manipulation" (1999), bahwa ada beberapa prediktor dari manipulasi Iaporan keuangan yang dapat digunakan. Beneish Ratio Index yang digunakan untuk mendeteksi adanya manipulasi dalam laporan keuangan tersebut antara lain:

a. Days Sales in Receivable Index (DSRI)

DSRI merupakan rasio jumlah hari penjualan dalam piutang pada tahun pertama (tahun $\mathrm{t}$ ) terhadap pengukuran tahun sebel umnya (tahun t-1). DSRI 
Mendeteksi

Kecurangan

Laporan

Keuangan...

28

mengukur apakah posisi piutang dan pendapatan sudah seimbang selama 2 tahun berturut-turut. Angka DSRI yang tinggi mengindikasikan bahwa perusahaan melakukan perubahan kebijakan kredit untuk memacu penjualan. Namun peningkatan piutang dapat disebabkan oleh inflasi. Rumus DSRI adalah sebagai berikut:

$$
\text { DSRI }=\frac{(\text { AccountReceivablet }: \text { Salest })}{(\text { AccountReceivablest }-1: \text { Salest }-1)}
$$

b. Gross Margin Index (GMI)

GMI merupakan rasio gross margin dalam tahun sebelumnya (tahun t-1) terdapat gross margin tahun pertama (tahun t). Jika nilai GMI >1 mengindikasikan perusahaan memiliki sinyal negatif dari segi prospek perusahaan. J ika perusahaan memiliki prospek negatif maka akan lebih rentan melakukan manipulasi laporan keuangan. Rumus GMI adalah sebagai berikut:

$$
\mathrm{GMI}=\frac{\text { Sales }_{t-1}-\text { Costof Sales }_{t-1}}{\frac{\text { Salest }-1^{\text {Sales }}-\text { Costof Sales }_{t}}{\text { Salest }}}
$$

c. Asset Quality Index (AQI)

AQI merupakan rasio noncurrent assets terhadap total assets yang mengukur proporsi total aset terhadap keuntungan di masa mendatang yang kurang memiliki kepastian. J ikaAQI >1 mengindikasikan bahwa perusahaan memiliki kemungkinan lebih besar untuk meningkatkan biaya tangguhan atau meningkatkan aset tidak berwujud dan memanipulasi pendapatan. Semakin besar nilai AQI merupakan sebuah indikasi penurunan kualitas aset dan semakin besar memanipulasi pendapatan. RumusAQI adalah sebagai berikut:

$$
\mathrm{AQI}=\frac{1-\text { CurrentAsse }_{t}+\frac{\text { NetFixedAsset }_{t}}{\text { TotalAsset }_{t}}}{1-\text { CurrentAssets }_{t-1}+\frac{\text { NetFixedAssets } t-1}{\text { TotalAsset }_{t-1}}}
$$

d. Sales Growth Index (SGI)

SGI merupakan rasio penjualan pada tahun pertama (tahun $\mathrm{t}$ ) terhadap penjualan tahun sebelumnya (tahun t-1). Hasil SGI $>1$ menggambarkan perusahaan mengalami peningkatan penjualan dari tahun sebelumnya. Perusahaan yang mengalami pertumbuhan penjualan lebih cenderung melakukan mani pulasi terhadap pendapatan. Rumus dari SGI adal ah sebagai berikut:

$$
\mathrm{SGI}=\frac{\text { Sales }_{t}}{\text { Sales }_{t-1}}
$$

e. Total Accruals to Total Assets (TATA)

TATA merupakan rasio total accruals terhadap total assets. Dimana total accruals diperhitungkan sebagai perubahan akun modal kerja selain kas dan piutang pajak dikurangi depresiasi. Rasio ini memperkirakan ramalan jangka pendek aktivitas pemasukan dan pengeluaran dari sebuah perusahaan. Rumus dari TATA adalah sebagai berikut:

$\Delta$ Working Capital $-\Delta$ Cash $-\Delta$ Current Taxes Payable - Depreciation and amortisation. 
Penelitian ini merupakan jenis penelitian deskriptif. Teknik pengumpulan data dalam penelitian ini adalah menggunakan dokumentasi. J enis data yang diperoleh adalah data sekunder, yaitu data laporan keuangan perusahaan yang menjadi objek penelitian. Adapun teknik analisis data laporan keuangan perusahaan menggunakan rasio index. Perhitungan rasio index digunakan sebagai acuan untuk menentukan perusahaan tergol ong manipulators atau non manipulators. Perusahaan dikategorikan manipulators atau non manipulators apabila memperol eh nilai M-Scoresesuai dengan parameter index menurut Beneish Model. Berikut cara menentukan perusahaan tergolong manipulators atau non manipulators.

a Perusahaan yang memiliki $\geq 3$ (tiga) indeks hitung yang sesuai dengan indeks parameter yang menyatakan Manipulators, tergolong kedalam perusahaan Manipulators.

b Perusahaan yang memiliki $\geq 3$ (tiga) indeks hitung yang sesuai dengan indeks parameter yang menyatakan Non Manipulators, tergolong kedalam perusahaan Non Manipulators.

c Perusahaan yang memiliki $\geq 3$ (tiga) indeks hitung yang sesuai dengan indeks parameter yang menyatakan grey, dan indeks hitung yang tidak memenuhi 2 (dua) kriteria penggolongan Manipulators dan Non Manipulators digolongkan perusahaan grey (Grey Company).

\section{HASIL DAN PEMBAHASAN}

Tindakan pencegahan dalam mencegah kecurangan sangat penting ter utama bagi pemilik usaha. M etodeaudit dan statistik dilaporkan sebagai strategi terbaik untuk mendeteksi kecurangan (Aris, et.al, 2013). Dengan meningkatnya jumlah perusahaan yang menggunakan praktik curang ini, auditor menjadi terbebani dengan tugas mendeteksi kecurangan. Dalam membantu profesionalitas auditor untuk analisis risiko dan deteksi kecurangan, metode statistik berfungsi sebagai al at populer yang digunakan oleh organisasi bisnis dan pemerintah. Pengetahuan dan pemahaman yang baik tentang sistem akuntansi sangat penting untuk menentukan strategi akurat yang dapat diadopsi dalam deteksi kecurangan. Strategi deteksi kecurangan statistik bergantung pada metode analisis dan dipandang lebih efisien daripada strategi lainnya (Perols, 2011).

Penelitian ini mengadopsi tiga teknik statistik yaitu Beneish M-Score, Altman Z-Score dan Rasio Keuangan. M-Score Beneish adalah model matematis yang terdiri dari delapan variabel untuk mengidentifikasi keberadaan kecurangan keuangan atau kecenderungan untuk terlibat dal am mani pulasi penghasilan. Altman Z-Score dihitung untuk memprediksi kemungkinan perusahaan tersebut mengalami kebangkrutan. Rasio keuangan yang berfokus pada profitabilitas, likuiditas, efisiensi dan keselamatan merupakan analisis yang disukai dalam mengukur kinerja perusahaan. Temuan ini akan berfungsi sebagai bantuan dalam mengidentifikasi bi dang manipulasi berdasarkan variabel yang termasuk dalam analisis. Namun, ini hanya berfungsi sebagai titik awal penyelidikan. Penyelidikan lebih Ianjut diperlukan untuk mendeteksi aktivitas penipuan yang terjadi di perusahaan. Ini juga bisa digunakan dalam memperbaiki operasi perusahaan.

\section{Input Variabel}

Analisis dan pembahasan pada penelitian ini mencakup periode dua tahun yang mencakup tahun 2015 dan 2016. Dengan demikian, Iaporan keuangan tiga 
Mendeteksi

Kecurangan

Laporan

Keuangan...

30 tahun yang diaudit (2014 sampai 2016) dibutuhkan dan diperoleh dari perusahaan. Rincian ditunjukkan pada Tabel 1 di bawah ini.

\section{Model Beneish}

Beneish M-Score adalah model matematika yang diciptakan oleh Profesor Messod Daniel Beneish. Model terdiri dari delapan variabel untuk mengidentifikasi terjadinya kecurangan keuangan atau kecenderungan untuk terlibat dalam manipulasi pendapatan (J ones, Krishnan, \& Melendrez, 2008). M-Score kurang dari -2.22 menunjukkan bahwa perusahaan tidak akan menjadi manipulator. MScore lebih besar dari -2.22 memberi sinyal bahwa perusahaan cenderung menjadi manipulator. Hasil dari model ini sangat membantu dalam mengidentifikasi manipulator dan bi dang mani pulasi berdasarkan variabel yang termasuk dalam model. Delapan variabel yang digunakan untuk mengembangkan M-Score dinyatakan dalam persamaan sebagai berikut:

M score $=-4.84+0.92 \mathrm{DSRI}+0.528 \mathrm{GMI}+0.404 \mathrm{AQI}+0.892 \mathrm{SGI}+0.115 \mathrm{DEPI}$ - 0.172 SGAI + 4.679 TATA - 0.327 LVG

Berdasarkan rumus di atas, penelitian ini berhasil menghitung $\mathrm{M}$-Score untuk perusahaan seperti terlihat pada Tabel 2. M-Score perusahaan lebih besar dari -2,22 pada tahun 2016 dan lebih rendah dari -2,22 pada tahun 2015. Dengan demikian, ada kemungkinan manipulasi laba pada tahun 2016. Pada tahun 2016 AQI (1.443> 1.254) dan DEPI (1.48>1.0) kemungkinan merupakan area yang dimanipulasi, hal ini karena skor keduanya melampaui skor patokan.

Berdasarkan tabel di atas diketahui bahwa GMI dan DSRI dapat menimbulkan ancaman karena ada kemungkinan manipulasi. Skor SGI yang lebih rendah dan nilai GMI yang lebih tinggi tidak konsisten karena kenaikan marjin kotor diperkirakan dihasilkan ol eh penjual an yang lebih tinggi. Dengan demikian penyelidikan lebih Ianjut harus dilakukan terutama di bidang penjualan, Iaba kotor dan piutang usaha.

\begin{tabular}{lrrr}
\hline & \multicolumn{1}{c}{$\mathbf{2 0 1 4}$} & \multicolumn{1}{c}{$\mathbf{2 0 1 5}$} & \multicolumn{1}{c}{$\mathbf{2 0 1 6}$} \\
\hline Net Sales & $147,716,000$ & $134,793,221$ & $142,071,708$ \\
Cost of Goods Sold & $126,042,366$ & $118,696,106$ & $125,266,321$ \\
Net Receivables & $24,437,401$ & $36,788,794$ & $42,707,421$ \\
Current Assets & $63,977,088$ & $55,106,437$ & $49,376,042$ \\
PPE & $33,449,446$ & $40,487,780$ & $44,544,983$ \\
Total Assets & $104,748,887$ & $102,381,447$ & $103,852,915$ \\
SG A Expense & $7,777,720$ & $5,658,495$ & $5,095,453$ \\
Net Profit & $12,395,746$ & $9,146,906$ & $12,555,675$ \\
Cash Flow from Operations & $4,743,470$ & $10,893,306$ & $25,357,907$ \\
Current Liabilities & $39,349,837$ & $43,695,677$ & $41,229,554$ \\
Long-term Debt & $22,818,572$ & $9,348,731$ & $2,657,638$ \\
\hline
\end{tabular}

Hasil M score disajikan pada tabel 2 berikut:

\begin{tabular}{lccc}
\hline & Patokan & $\mathbf{2 0 1 5}$ & $\mathbf{2 0 1 6}$ \\
\hline SGI & $>1.607$ & 0.913 & 1.054 \\
GMI & $>1.193$ & $\mathbf{1 . 2 2 9}$ & 1.010 \\
AQI & $>1.254$ & 0.948 & $\mathbf{1 . 4 4 3}$ \\
DSRI & $>1.165$ & $\mathbf{1 . 6 5 0}$ & 1.101 \\
SGAI & $>1.041$ & 0.797 & 0.854 \\
DEPI & $>1.000$ & 0.959 & $\mathbf{1 . 4 8 0}$ \\
LVGI & $>1.000$ & 0.873 & 0.816 \\
TATA & $>0.018$ & -0.017 & -0.123 \\
M-SCORE & $>\mathbf{- 2 . 2}$ & $\mathbf{- 1 . 8 7}$ & $\mathbf{- 2 . 5 9}$ \\
\hline
\end{tabular}


Skor di bawah 1,8 berarti perusahaan mungkin menuju kebangkrutan, sementara perusahaan dengan nilai di atas 3,0 tidak mungkin bangkrut. Singkatnya, semakin rendah nilai, semakin tinggi kemungkinan kebangkrutan. Rumusnya dapat digunakan untuk memprediksi probabilitas bahwa perusahaan akan bangkrut dalam waktu dua tahun. Z-score digunakan untuk memprediksi default perusahaan dan ukuran kontrol yang mudah dihitung untuk status distress keuangan perusahaan dalam studi akademis. Nilai Z menggunakan beberapa nilai pendapatan dan neraca perusahaan untuk mengukur kesehatan finansial suatu perusahaan. Altman Z-Score dihitung sebagai berikut:

Z-Score $=1.2 \times 1+1.4 \times 2+3.3 \times 3+0.6 \times 4+0.999 \times 5$

Berdasarkan rumus dan data yang tersedia, hasilnya telah dihitung sesuai Tabel 3 di bawah ini.

Hasilnya menunjukkan bahwa perusahaan berada dalam posisi yang sehat karena skornya di atas 3,0 untuk kedua tahun. Secara individual, semua nilai memberikan pertumbuhan positif dengan nilai pasar ekuitas terhadap total kewajiban mencatat kenaikan tertinggi sebesar $47 \%$ dari tahun sebel umnya. Skor keseluruhan bisa menarik investor karena menandakan pertumbuhan.

\section{Rasio Keuangan}

Analisis rasio yang biasa digunakan dalam menilai kinerja perusahaan yaitu profitabilitas, efisiensi, likuiditas dan kesel amatan. Rasio Profitabilitas (marjin laba kotor, marjin laba bersih, return on assets dan return on equity) mengukur kemampuan perusahaan untuk menghasilkan laba atas sumber dayanya. Likuiditas ditunjukkan oleh rasio lancar yang mengukur kemampuan perusahaan untuk membayar kewajibannya dal amjangka pendek. Rasioyang semakin tinggi semakin kuat adalah kemampuan perusahaan untuk membayar kewajibannya saat jatuh tempo, dan yang lebih rendah adalah risiko gagal bayar. Efisiensi mengevaluasi seberapa baik perusahaan mengel ola asetnya dengan menggunakan empat rasio; omset piutang, perputaran hutang, perputaran persediaan dan penjualan ketotal aset. Keselamatan menunjukkan kerentanan perusahaan terhadap risi ko hutang dan diukur dengan menggunakan hutang terhadap ekuitas, EBIT atas bunga dan arus kas terhadap hutang jangka panjang saat ini.

Kecurangan keuangan dapat dilakukan untuk menaikkan harga saham, menghindari pembayaran pajak atau mendapatkan pinjaman dari bank dengan membagikan dividen yang lebi $\mathrm{h}$ rendah kepada pemegang saham. Saat ini semakin banyak perusahaan memanfaatkan kecurangan untuk menutupi status keuangan mereka yang sebenarnya dan membuat keuntungan dengan mengorbankan pemegang saham (Ravisankar et al., 2011). Dengan menggunakan laporan keuangan

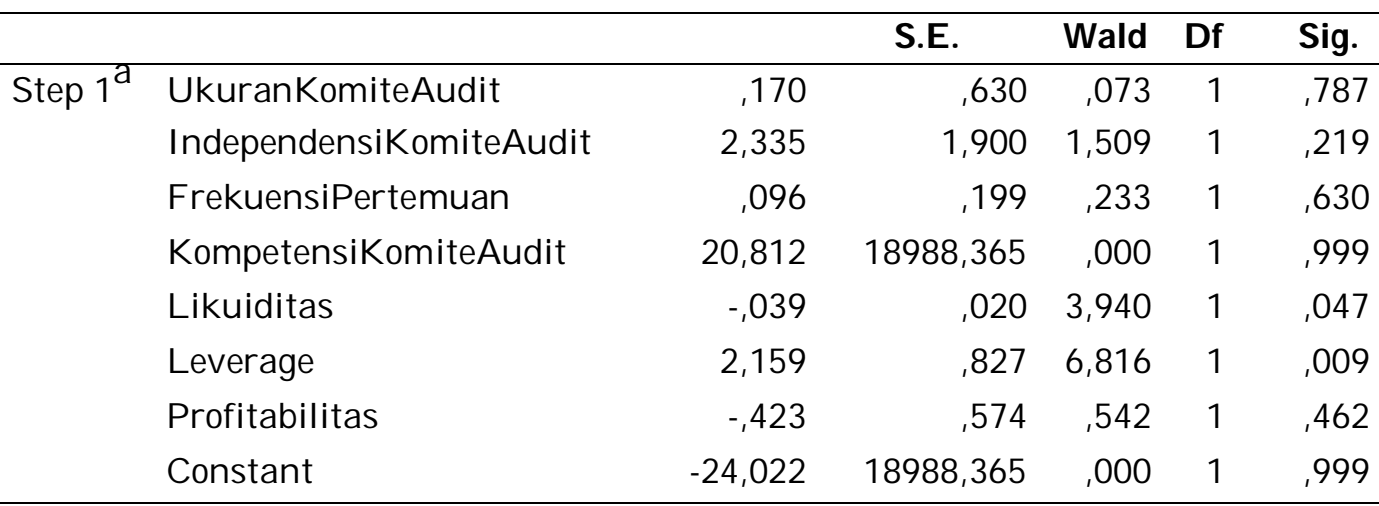

Tabel 3.

Hasil Z-Score 
Mendeteksi

Kecurangan

Laporan

Keuangan...

32

Tabel 4.

Hasil Rasio

Keuangan Tahun

2015 dan 2016 perusahaan yang telah diaudit, hasil yang dihitung ditampilkan pada Tabel 4 di bawah ini.

\begin{tabular}{|c|c|c|c|c|}
\hline No & Indikator & Formula & 2015 & 2016 \\
\hline \multirow[t]{3}{*}{1.} & Profitability Ratio & & & \\
\hline & Gross Profit Margin & Gross profit / Total sales & $12 \%$ & $12 \%$ \\
\hline & Net Profit Margin & Net profit / Total sales & $7 \%$ & $9 \%$ \\
\hline \multirow[t]{3}{*}{2.} & Liquidity ratio & & & \\
\hline & Current Ratio & $\begin{array}{l}\text { Current asset / Current } \\
\text { liabilities }\end{array}$ & 1.3 & 1.2 \\
\hline & Quick test Ratio & $\begin{array}{l}\text { Cash +AR / Current } \\
\text { liabilities }\end{array}$ & 0.9 & 0.7 \\
\hline \multirow[t]{8}{*}{3.} & $\begin{array}{l}\text { Efficiency ratio } \\
\text { Accounts Receivable } \\
\text { Turnover }\end{array}$ & $\begin{array}{l}\text { Credit sales / Average } \\
\text { Accounts Receivable }\end{array}$ & 6.5 & 5.5 \\
\hline & $\begin{array}{l}\text { Days in Sales } \\
\text { Receivable }\end{array}$ & $\begin{array}{l}\text { Account Receivables * } 360 \text { / } \\
\text { Sales }\end{array}$ & 69.3 hari & $\begin{array}{l}66.1 \\
\text { hari }\end{array}$ \\
\hline & $\begin{array}{l}\text { Accounts Payable } \\
\text { Turnover }\end{array}$ & $\begin{array}{l}\text { Credit purchases / Average } \\
\text { Accounts Payable }\end{array}$ & 5.1 & 4.5 \\
\hline & Days in Payables & $\begin{array}{l}\text { Accounts Payable* } 360 \text { / } \\
\text { Sales }\end{array}$ & 84.3 hari & $\begin{array}{l}81.6 \\
\text { hari }\end{array}$ \\
\hline & $\begin{array}{l}\text { Inventory Turnover } \\
\text { Ratio }\end{array}$ & COGS / Average I nventory & 42.3 & 30.4 \\
\hline & Days in Sales Inventory & Inventory * 360 / Sales & 8.5 hari & $\begin{array}{l}11.9 \\
\text { hari }\end{array}$ \\
\hline & $\begin{array}{l}\text { Cost of Goods } \\
\text { Percentage }\end{array}$ & COGS / Sales & $88 \%$ & $88 \%$ \\
\hline & PPE Turnover & Sales / Average PPE & $3.6(40 \%)$ & $\begin{array}{c}3.3 \\
(43 \%)\end{array}$ \\
\hline \multirow[t]{3}{*}{4.} & Safety & & & \\
\hline & Debt to Equity & TL / Equity & $1.1(52 \%)$ & $\begin{array}{c}0.7 \\
(42 \%)\end{array}$ \\
\hline & Earnings Per Share & Net income/No. of Shares & 2.98 & 2.17 \\
\hline
\end{tabular}

Hasilnya menunjukkan bahwa perusahaan berhasil mempertahankan dan meningkatkan profitabilitas pada tahun 2016 dibandingkan dengan tahun 2015. ROA dan ROE tidak ditunjukkan karena telah tercakup dalam Altman Z-Score. Posisi likuiditas perusahaan menyebabkan kekhawatiran karena mengindikasikan kemampuan perusahaan untuk mel unasi kewaji bannya sangat minim. Kedua hasil rasio uji lancar dan cepat dapat dikatakan buruk. Hal ini bisa dijelaskan dengan melihat rasio efisiensi. J angka waktu kredit perusahaan melampaui 60 hari yaitu dua bulan setelah penjualan. Sedangkan hutang lebih dari 80 hari yang menunjukkan bahwa perusahaan mungkin harus menunggu piutangnya sebelum membayar pemasok. Alasan dibalik persyaratan utang jangka panjang biasanya adalah upaya col lecting yang buruk, keterlambatan pembayaran pelanggan atau pelanggan berada dalam posisi keuangan yang lemah. Melihat ke klien perusahaan, kemungkinan pembayaran akan tertunda.

Strategi pemberian pinjaman untuk usaha kecil menengah mungkin tidak berjalan baik dalam jangka panjang karena uang tunai sangat penting dalam bisnis apa pun. Perputaran persediaan telah ditingkatkan dari 42 hari menjadi 30 hari yang mengurangi biaya gudang dan administrasi dan posisi APD berada pada tingkat yang memuaskan. Rasio hutang terhadap ekuitas memberi sinyal bahwa perusahaan berusaha memanfaatkan pembiayaan internal nya daripada meminjam dari bank. Hal ini tercermin pada EPS, dimana 2016 mencatat nilai yang lebih tinggi dibandingkan tahun 2015. Kesimpulannya, perusahaan perlu memperbaiki posisi likuiditas dan efisiensinya. 
Usaha kecil menghadapi risiko penipuan yang berbeda dari yang dihadapi ol eh bisnis yang lebi h besar. Oleh karena itu, usaha kecil dan menengah ini harus lebih diperhatikan karena secara statistik, organisasi dengan kurang dari 100 karyawan mengalami lebih banyak kasus penipuan daripada perusahaan yang lebih besar.

Peneliti pertama kali mengidentifikasi kemungkinan perusahaan tersebut memanipulator pendapatan dengan Beneish M-score. M-score untuk 2015 lebih tinggi dari patokan -2.22, yang mengindikasikan kemungkinan aktivitas manipulasi laba. Bidang investigasi selanjutnya adalah GMI dan DSRI. Meski hasilnya untuk 2016 bisa diterima, skor individu bisa digunakan dalam menilai risiko kecurangan. AQI dan DEPI harus diselidiki untuk memastikan manipulasi tidak berkepanjangan. Altman Z-Score kemudian dihitung untuk menguji risiko kebangkrutan. Hasilnya menunjukkan bahwa perusahaan itu aman dan sama sekali tidak menghadapi risiko bangkrut. Terakhir, analisis rasio dilakukan meli puti empat bidang keuangan yaitu; profitabilitas, efisiensi, likuiditas dan cakupan dan pendanaan. Hasilnya menunjukkan bahwa likuiditas dan efisiensi adalah dua wilayah berisiko yang perlu diselidiki lebih lanjut.

Berdasarkan tiga analisis statistik yang dilakukan untuk tahun 2015 dan 2016, dapat di simpulkan bahwa ada daerah yang perlu penyelidikan lebi Ianjut. Hasil dari analisis ini sangat membantu dalam mengi dentifikasi mani pulator dan area manipulasi berdasarkan variabel yang termasuk dalam model. Namun, itu hanya titik awal dari penyelidikan. Hal ini pada dasarnya peran manajemen dalam memastikan operasi dan kinerja perusahaan memenuhi tujuan perusahaan. Mengingat fakta bahwa waktu dan sumber daya pengelolaan terbatas, ada kebutuhan nyata bagi perusahaan dalam membentuk departemen pengendalian internal. Pengendalian internal sebagai sebuah proses yang dirancang untuk memberikan kepastian mengenai isu penting yaitu; efektivitas dan efisiensi operasi perusahaan, keandalan pelaporan keuangan dan kepatuhan terhadap peraturan dan undang-undang yang berlaku. Dipercaya bahwa pengendalian internal bisa memberi nilai tambah bagi perusahaan jika diterapkan dengan benar.

Kekurangan yang diidentifikasi dari temuan ini yaitu pentingnya membangun pengendalian internal yang kuat dalam penyusunan laporan keuangan yang akan memungkinkan perusahaan mengidentifikasi manipulasi lebih awal. Perbaikan dalam pengendalian internal sangat penting di area yang disorot. Oleh karena itu, auditor internal harus melihat keseluruhan prosedur yang terkait dengan area yang ditargetkan untuk mengidentifikasi kemungkinan alasan yang mempengaruhi situasi saat ini. Di dunia yang semakin kompleks, pelaku kecurangan sering mengembangkan alat dan peluang baru untuk berbohong dan menipu. Namun, manajemen perusahaan memiliki kesempatan yang sama untuk menggunakan teknologi dan pengetahuan baru dalam rangka mengembangkan alat dan proses yang akan membantu memerangi penipuan.

\section{DAFTAR PUSTAKA}

ACFE (Association of Certified Fraud Examiner). 2014. Report to the Nations on Occupational Fraud and Abuse.

Albrecht W. S dan Albrecht Chad O. 2002. Fraud Examination. J ournal Academic Ethic. Volume 7.

Aris, Abdul N., Othman, R., Mohd Arif, S. M., Abdul Malek, M. A., \& Omar, N. 2013. Fraud Detection: Benford's Law vs Benei sh Model. In IE E E Symposium in Humanities, Science Research (SHUSER) .

Beneish, Messod D. 1999. The Detection of Earnings Manipulation. Financial Analysis J ournal. 
Mendeteksi

Kecurangan

Laporan

Keuangan...

34

Berita Resmi Statistik D.I. Yogyakarta No. 09/02/34/Th.XVIII, 1 Februari 2016

Fahmi, Irham. 2012. Analisis Laporan Keuangan. Cetakan Ke-2. Bandung: Alfabeta.

IAI (I katan Akuntansi Indonesia). 2009. Standar Akuntansi Keuangan, PSAK No. 1: Penyajian Laporan Keuangan. J akarta: Salemba Empat. . 2012. Standar Akuntansi Keuangan. J akarta: Salemba Empat.

Isa, T. 2011. I mpacts And Losses Caused By The Fraudulent And Manipulated Financial I nformation On E conomic Decisions. Review of International Comparative Management, 12(5), 929-939. Dari http://www.academia.edu/download/30403610/ebeec2011proceedings. pdf \#page $=44$

J ackson, K. R., Holland, D. V., Albrecht, C., \& Woolstenhulme, D. R. 2010. Fraud I sn't J ust For Big Business: Understanding The Drivers, Consequences, And Prevention Of Fraud In Small Business. J ournal of I nternational.

J ones, K. L., Krishnan, G. V., \& Melendrez, K. D. 2008. Do Models of Discretionary Accruals Detect Actual Cases of Fraudulent and Restated Earnings? An Empirical Analysis. Contemporary Accounting Research, 25(2).

Perols, J . 2011. Financial Statement Fraud Detection: An Analysis of Statistical and Machine Learning Algorithms. Auditing: A J ournal of Practice \& Theory, 30(2).

Ravisankar, P., Ravi, V., Raghava Rao, G., \& Bose, I. 2011. Detection Of Financial Statement Fraud And Feature Sel ection Using Data Mining Techniques. Decision Support Systems, 50(2).

Rezaee, Zabihollah and Riley Richard. 2005. Prevention and Detection. Canada: J ohn Wiley \& Sons: Inc.

UNDP (United Nations Development Programme). 2006. Indonesia, Indeks Pembangunan Manusia. Jakarta: UNDP. 